УДК 327

МЕДУШЕВСКИЙ Николай Андреевич - доктор политических наук, профессор кафедры культуры мира и демократии Российского государственного гуманитарного университета (115446, Россия, 2. Москва, Коломенский пр., 21; Lucky5659@yandex.ru)

\title{
МИРОТВОРЧЕСКИЕ ОПЕРАЦИИ ПОД РУКОВОДСТВОМ АФРИКАНСКИХ СТРАН
}

Аннотация. Статья представляет собой рецензию на монографию «Africa's Role in Nation-Building. An Examination of African-Led Peace Operations", представляющую новый современный взгляд на миротворческую деятельность на Африканском континенте. В рамках данной работы Африканский союз и отдельные африканские государства представляются как автономный и достаточно успешный субъект миротворческой деятельности, который, по мнению авторов, в перспективе способен взять на себя ключевые функции миротворческого регулирования в Африке.

Ключевые слова: Африка, Африканский союз, коалиции стран, миротворческая деятельность, ООН

Д

анная статья написана в форме рецензии на коллективную монографию 2019 г. "Africa's Role in Nation-Building. An Examination of African-Led Peace Operations» [Dobbins et al. 2019]. Тематика монографии представляется крайне интересной для российского читателя. Современную Африку можно охарактеризовать как территорию противоречий, на которой столкнулись интересы многих развитых и развивающихся стран. Борьбу за ресурсы и за сферы влияния на континенте активно ведут Великобритания, Франция, ЕС, США, Китай, Россия, Индия, Бразилия и многие другие геополитические игроки. Их интересы, действия и политические практики часто становятся объектами пристального научного рассмотрения, что подчас формирует искаженное представление о реальной ситуации на континенте. Возникает восприятие, что сами африканские страны лишены субъектности и обречены идти и действовать в фарватере внешнего влияния.

Тем не менее это не вполне так, и на континенте достаточно интенсивно развиваются процессы интеграции, межстранового диалога и кооперации, что соответствует восприятию странами региона глобальной политической и экономической повестки, а также необходимости реагировать на общерегиональные вызовы, в числе которых природные катаклизмы, воины, миграция и терроризм.

В данной связи монография «Africa's Role in Nation-Building» представляет особый интерес, т.к. посвящена именно вопросам континентальной политики, хотя и ангажирована американским подходом, т.к. издателем публикации выступила всемирно известная американская фабрика мысли $R A N D$ Corporation, которая до этого уже публиковала аналогичные работы, написанные с позиции США, ООН и Европы.

Монография «Africa's Role in Nation-Building» рассматривает вопросы поддержания мира, принуждения к миру и постконфликтной стабилизации, связанные с деятельностью африканских государств, а также региональных организаций, в числе которых ключевая роль отводится Африканскому союзу.

Характерно, что авторы в своей работе уделяют внимание не только знаковым конфликтам, достаточно широко описанным и в российской научной литературе, но также обращают внимание и на латентные конфликты, а также вопросы эскалации конфликтогенности в относительно стабильных регионах. 
Монография содержит тематические исследования шести миссий, реализованных в т.ч. в Бурунди, Центральноафриканской республике, Дарфуре, на Коморских островах, в Сомали и бассейне озера Чад.

За тематическими исследованиями следует статистическое сравнение миссий США, ООН, Европы и Африки, что повышает научную ценность исследования и делает его востребованным источником в проведении исследовательских работ по африканской проблематике.

Монография несет в себе не только функцию популяризации информации, но также содержит аналитические рекомендации для ООН, организаций и правительств, заинтересованных в реализации политики на Африканском континенте.

Характеризуя представленное исследование в целом, следует отметить, что в нем ставятся три основных исследовательских вопроса.

В первую очередь авторы изучают результаты политики африканских государств и подготовленных ими миссий в Бурунди, Центральноафриканской республике, Дарфуре, на Коморских островах, в Сомали и бассейне озера Чад. Далее анализируются мандаты, размеры и другие номинальные характеристики миссий. Третий вопрос, который находит свой ответ в исследовании, связан с тем, как обозначенные миссии справились с поставленными задачами и каковы были пути решения, в т.ч. в области обеспечения безопасности, передачи гуманитарной помощи, управления и трансформации или воссоздания гражданской администрации, а также демократизации и экономического восстановления.

Исследователи не абсолютизируют роль и эффективность миссий. Они констатируют, что из шести рассмотренных миссий две были в конечном счете успешными, а три показали относительный прогресс.

В связи с тем, что исследование посвящено именно деятельности африканских государств и организаций, большое внимание исследователи уделяют общей оценке их деятельности в качестве автономной внутриконтинентальной силы, способной участвовать на первых ролях в реализации региональной миротворческой деятельности.

В данной связи позитивной оценки удостаивается общая институциональная роль Африки в региональных миротворческих операциях, выраженная в таких проявлениях, как уровень сотрудничества между государствами, включая страны, непосредственно затронутые конфликтами.

Несмотря на то что в африканской континентальной политике далеко не всегда присутствует консенсус между участниками, на примере обозначенных конфликтов, по мнению авторов исследования, стороны показали готовность и способность к проведению эффективных многосторонних консультаций, а также к созданию специальных целевых коалиций для реализации общих интересов.

По мнению авторов исследования, миротворческие операции под руководством африканских стран в Бурунди, Центральноафриканской республике, Дарфуре, на Коморских островах, в Сомали и бассейне озера Чад продемонстрировали гибкость в решении целого ряда различных задач, в числе которых коллективное ведение боевых действий, деятельность в рамках субрегиональных или общеконтинентальных учреждений и сотрудничество с внешними партнерами.

С учетом того, что публикация ангажирована американскими интересами в регионе, последний фактор для исследователей, видимо, представляет особый интерес, т.к. открывает новые возможности внешнего трансрегионального влияния. В связи с этим исследователи констатируют, что африканские 
наднациональные учреждения в перспективе скорее всего создадут новые возможности для проведения миротворческих операций, особенно если появятся новые средства (предположительно, внешнего характера).

Подводя итог обзора монографии «Africa's Role in Nation-Building. An Examination of African-Led Peace Operations», следует обратиться к общим выводам данного исследования, которые, на наш взгляд, имеют общенаучное применительно к исследованию региональной политики значение.

Так, авторы исследования констатируют достаточно высокий уровень проведения африканскими коалициями миротворческих миссий, в т.ч. и в кризисных ситуациях, где африканские миротворцы выступали в качестве сил последней инстанции, берущих на себя задачи, которые другие учреждения отвергают.

По мнению исследователей, успех изучаемых миссий относителен, но в целом позитивен, т.к. две из шести рассмотренных африканских операций (Бурунди и Коморские острова) помогли установить относительно мирный курс политического и социального развития, а еще три миссии, хотя и не увенчались успехом, способствовали укреплению региональной безопасности (хотя, конечно, многие российские исследователи выступили бы против данного тезиса, аргументируя свою позицию данными региональной статистики).

Еще один вывод, который сформулировали авторы работы, связан с большей точностью миссий, реализуемых африканскими коалициями, в отличие, к примеру, от миссий ООН, что обусловлено лучшим пониманием региональных условий и вызовов.

В итоге авторы констатируют, что роль африканских коалиций и Африканского союза в вопросах миротворчества растет, хотя превалирующей остается роль ООН и, как это обозначено в исследовании, «других партнеров», которые обладают большими ресурсами и организационным потенциалом, что, по мнению авторов, не вполне справедливо и требует корректировки, которая может быть выражена в том, чтобы Африканскому союзу было позволено собирать средства на миротворчество, облагая налогом импорт стран континента в размере $0,2 \%$, а также в разработке типовых моделей сотрудничества с ООН и другими неафриканскими организациями, «чтобы избежать начала каждой миссии с нуля».

Несмотря на оригинальность подобных предложений авторов исследования и признавая за ними наличие определенной логики, на наш взгляд, нельзя некритически рассматривать данный раздел исследования. Наша авторская позиция в данном случае выражается в том, что аналитики RAND Corporation, подготовившие данное исследование, вероятно, умышленно не хотят видеть правосубъектности африканских стран, каждая из которых, являясь членом $\mathrm{OOH}$, вправе выбирать путь своего развития и внешней политики, часто вопреки региональным или глобальным интересам. Принятие же итоговых предложений, сформулированных в монографии, безусловно, повысит престиж Африканского союза и сделает его более активным в вопросах миротворческой политики на континенте, но при этом дистанцирует его от ООН и, вполне возможно, подвергнет экономической зависимости от других «внешних партнеров», имеющих собственное видение правильного развития африканских государств. 


\section{Список литературы}

Dobbins J., Pumzile Machakaire J., Radin A., Pezard St., Blake J.S., Bosco L., Chandler N., Langa W., Nyuykonge Ch., Fabrice Tunda K. 2019. Africa's Role in Nation-Building: An Examination of African-Led Peace Operations. RAND Corporation. St. Monika. 320 p.

MEDUSHEVSKIY Nikolai Andreevich, Dr.Sci. (Pol.Sci.), Professor of the Chair of Peace Culture and Democracy, Russian State University for the Humanities (21 Kolomensky Pass, Moscow, Russia, 115446; Lucky5659@ yandex.ru)

\section{AFRICAN-LED PEACE OPERATIONS}

Abstract. The article is a review of the monograph «Africa's Role in Nation-Building. An Examination of African-Led Peace Operations", presenting a new modern perspective on peacekeeping activities on the African continent. Within the framework of this work, the African Union and individual African states are presented as an autonomous and rather successful subjects of peacekeeping activities, which, according to the authors, in the future is capable of taking on the key functions of peacekeeping regulation in Africa.

Keywords: Africa, African Union, coalitions of countries, peacekeeping activities, UN 